\title{
A INTERDISCIPLINARIEDADE Á LUZ DA HISTORIA DA CIENCIA: ALGÚNS EXEMPLOS TOMADOS DA FÍSICA, A MATEMÁTICA, A MEDICINA E AS CIENCIAS DA TERRA
}

José Manuel Sánchez Ron Universidad Autónoma de Madrid 



\section{INTERDISCIPLINARIEDADE}

A historia da ciencia mostra canto avanzamos no coñecemento da natureza dividíndoa en compartimentos máis ou menos estancos, é dicir, en disciplinas como a Matemática, a Física, a Química, a Bioloxía ou a Xeoloxía. Entusiasmados por semellantes purezas disciplinares, tendemos a esquecer que a natureza é unha, que non coñece divisións tales. E non só isto tan obvio, senón que esa historia da ciencia contén no seu seo episodios que revelan o frutíferas que son as análises interdisciplinares, é dicir, os coñecementos e técnicas que transcenden unha disciplina científica e reúnen varias. É o meu propósito nesta conferencia mostrar algúns exemplos en tal sentido, dos que se poden extraer valiosas conclusións, especialmente se temos en conta que, ao meu ver, o camiño que está a seguir a ciencia nas últimas décadas é, cada vez máis, o da interdisciplinariedade, algo natural por outra parte, xa que as disciplinas tradicionais están, en máis dun sentido, chegando ao seu límite; necesitan penetrar e ser penetradas por outras para así cumprir o obxectivo último da ciencia, que non é outro que o de describir, explicar -ser capaces de predicir- os fenómenos que se producen na natureza.

\section{O PRINCIPIO DE CONSERVACIÓN DA ENERXÍA: FISIOLOXÍA E FÍSICA}

Calquera que teña algunhas nocións de Física sabe moi ben que un dos seus útiles máis prezados é o principio de conservación da enerxía. Se non se sabe nada da historia da Física pode pensarse que a formulación de tal principio é debida unicamente aos físicos. Pois ben, non é así.

Nas primeiras décadas do século XIX aínda persistía entre médicos e moitos científicos a crenza de que a vida non se podía explicar tan só en termos das 
forzas que utilizaban físicos e químicos e que cumpría acudir a un principio vital.

Pero houbo quen non pensaba isto, quen combatía os principios vitalistas na procura de darlle á Medicina unha base científica. Convencidos de que os procesos vitais obedecían a leis deterministas da natureza, argumentaban que a Medicina, a verdadeira, é dicir, a Medicina científica, debería ter como obxectivo determinar como se comportaban os corpos, suxeitos a tales leis, baixo condicións alteradas. Así, nas súas declaracións programáticas, estes individuos facían fincapé na utilización de experimentos fisiolóxicos, Anatomía Patolóxica, Microscopia, Química, Física e, por suposto, observacións clínicas, como as ferramentas básicas para analizar as funcións corporais e a aparición de enfermidades, e para iso precisaban instrumentos refinados. É ilustrativo o caso de Emil du Bois-Reymond (1818-1896), quen destacou polos seus traballos en Electrofisioloxía, unha disciplina cuxas orixes se poden asociar coa publicación das investigacións de Luigi Galvani (1737-1798), en 1791, con ras decapitadas e o subseguinte debate que mantivo con Alessandro Volta (1747-1827) sobre a natureza da electricidade animal, que levou a este a inventar a súa célebre pila eléctrica. Durante a súa carreira, Du Bois-Reymond concentrou as súas investigacións no desenvolvemento de dous tipos de instrumentos: eléctrodos para a condución de correntes bioeléctricas débiles sen distorsión, e aparatos para detectar e amplificar estas correntes. Esta liña de investigación, na que Medicina, Fisioloxía, Química e Física se fecundaban e enriquecían mutuamente, rematou por conducir á enunciación dun dos instrumentos máis fecundos para a ciencia dos séculos XIX e XX, o principio de conservación da enerxía, formulado na súa forma máis xeral por Hermann von Helmholtz (1821-1894), en 1847.

O exemplo de Hermann von Helmholtz é especialmente significativo. Nacido en Postdam, en 1838, Helmholtz trasladou a súa residencia a Berlín para iniciar os seus estudos médicos no Instituto Real Federico Guillermo Médico-Cirúrxico, unha escola de Medicina destinada a formar médicos militares. $\mathrm{O}$ feito de elixir esta escola foi debido a que a súa familia non tiña os medios suficientes, e no Friedrich-Wilhelm Institut os estudantes non tiñan que pagar -recibían, ao contrario, un estipendio-, a cambio de comprometerse a dedicar os oito anos posteriores á súa graduación ao servizo do exército prusiano. 
Logo de rematar os seus estudos, en outubro de 1843, Helmholtz foi nomeado oficial médico e destinado ao hospital militar de Potsdam, onde permaneceu cinco anos. Como as súas obrigas médicas non eran excesivas, puido compatibilizalas coa investigación e estableceu un pequeno laboratorio nun barracón, no que se dedicou a estudar a produción de calor durante a contracción muscular; decatouse de que a explicación da produción de calor animal en función de transformacións químicas nos seus músculos encaixaba perfectamente cos propósitos dunha física que non fose allea aos fenómenos orgánicos. Demostrou, daquela, que a calor non era transportada aos músculos a través dos nervios ou do sangue, senón que era producida polos propios tecidos. Cuantificando estes feitos fisiolóxicos deduciu un equivalente mecánico da calor que incorporou na súa gran memoria de 1847, Über die Erhaltung der Kraft (Sobre a conservación da forza -enerxía para nós-).

Vexamos como se referiu Helmholtz ao seu descubrimento na súa autobiografía:

Naquela época a meirande parte dos fisiólogos adoptaran a solución de G. E. Stahl, é dicir, que malia seren as forzas físicas e químicas dos órganos e substancias do corpo vivo as que actúan sobre el, existe tamén dentro del unha alma ou forza vital que controla as actividades destas forzas. Despois da morte, a libre acción destas forzas físicas e químicas produce a descomposición, pero durante a vida a súa acción está constantemente regulada pola alma vital. Eu tiña a sensación de que nesta explicación existía algo contrario á natureza; custoume moito esforzo, así e todo, expresar as miñas dúbidas en forma dunha pregunta definida. Finalmente, durante o último ano da miña carreira como estudante, decateime de que a teoría de Stahl trataba a todo corpo vivente como se fose un perpetuum mobile. Eu estaba bastante ben informado das controversias relativas ao tema do movemento perpetuo e escoitara discutir sobre iso ao meu pai e aos nosos mestres de Matemáticas durante os meus días escolares. Ademais, como estudante no Instituto Friedrich-Wilhelm axudara na biblioteca, e no meu tempo de lecer examinara os traballos de Daniel Bernoulli, D’Alembert e outros matemáticos do pasado século. Desta maneira cheguei a preguntarme: que relacións deben existir entre as diversas forzas naturais para que sexa posible o movemento perpetuo?, e existen realmente tales relacións? $\mathrm{Na}$ miña memoria $A$ conservación da forza a miña intención era simplemente subministrar un exame crítico destas cuestións e presentar os feitos para beneficio dos fisiólogos. 
A historia do principio de conservación da enerxía está, como vemos, asociada a diversas disciplinas; case poderiamos dicir del que constitúe un paradigma da mestizaxe. O feito de que fose un médico (Helmholtz) o que, realizando investigacións fisiolóxicas e beneficiándose dos coñecementos acumulados na Física, formulase en toda a súa xeneralidade o principio de conservación da enerxía ten lecturas evidentes e moi instrutivas. Como xa indiquei, este principio foi un dos instrumentos máis fecundos para a Física do dezanove, unha rama da ciencia que naquela centuria experimentou un desenvolvemento que nos fai lembrar, cando o contemplamos retrospectivamente, os producidos nos tempos de Newton. E non só daquela época, xa que segue a ser hoxe un dos piares da Física. Pois ben, ese piar recibiu a súa forma definitiva dentro dunha disciplina que non era a Física, un detalle que nos mostra que non é posible entender a historia da Física do século XIX sen tomar en conta, así mesmo, a da Medicina e a Fisioloxía. Precisamente debido a isto, podemos comprender a carreira académica de Helmholtz a partir de 1847.

En 1848, Helmholtz puido abandonar o exército e aceptar a oferta de ensinar Anatomía na Academia de Belas Artes de Berlín, onde só estivo un ano; de alí marchou a Königsberg como profesor asociado -catedrático desde 1851- de Fisioloxía e permaneceu seis anos, durante os que continuou as súas investigacións en Fisioloxía dos Nervios -mediu, por exemplo, a velocidade dos impulsos nerviosos- e entrou tamén na Óptica e Acústica Fisiolóxica, áreas nas que seguiu interesado nos seguintes vinte anos. Mentres preparaba unha das súas clases, decatouse de que as sinxelas leis da Óptica Xeométrica lle permitían construír un instrumento de grande importancia potencial para a comunidade médica: o oftalmoscopio.

$\mathrm{O}$ que en realidade Helmholtz quería era describir o fenómeno -observado por William Cummings, un médico inglés, e por Ernst Brücke- mediante o que o ollo humano brilla nun cuarto escuro cando é iluminado e un observador permanece preto da fonte luminosa. Nin Cummings nin Brücke puideran ver a estrutura interna do ollo; sempre que se aproximaban o suficiente ao ollo para escudriñar dentro del, o escintileo procedente da fonte luminosa difundíase sobre toda a pupila. Helmholtz preguntouse, mentres preparaba a súa clase, como producían unha imaxe os raios de luz reflectidos; isto conduciuno a estudar as traxectorias dos raios, e descubriu que estes seguían camiños idénticos, 
tanto ao entrar como ao saír do ollo, o que lle permitiu explicar a incapacidade de Brücke para ver a estrutura interna. Para observala tería que situarse directamente na traxectoria dos raios e bloquearía así a fonte luminosa.

Unha vez interesado no problema, Helmholtz tardou unicamente oito días en resolvelo e en inventar un instrumento que lle permitise ver a retina dun ollo vivo.

En decembro de 1850, Helmholtz escribiulle ao seu pai para expresarlle a súa sorpresa porque ninguén antes ca el dera coa idea do oftalmoscopio, que -engadía- só precisaba unhas sinxelas leis de Óptica Xeométrica. Así e todo, subestimaba o coñecemento matemático que se necesitaba para comprender a Óptica Xeométrica en que se baseaba o oftalmoscopio, así como o valor da súa formación pluridisciplinar, algo que queda patente no que escribiu na súa autobiografía:

Coñecía ben, polos meus estudos médicos, as dificultades que tiñan os oftalmólogos cos problemas agrupados daquela baixo o nome de amaurose, e inmediatamente comecei a construír o instrumento, utilizando lentes de anteollos e láminas de vidro das empregadas nos mostrarios para os traballos con microscopio. As primeiras veces era difícil de usar, e de non ter a firme convicción teórica de que tiña que funcionar, non perseveraría. Ao cabo dunha semana, porén, tiven o gran pracer de ser o primeiro home en contemplar claramente unha retina humana nun ser vivo.

A construción do oftalmoscopio foi decisiva na miña consideración aos ollos do mundo. Desde aquel momento contei co recoñecemento inmediato das autoridades e dos meus colegas, así como cun forte afán por satisfacer os meus desexos. Fun quen, desta maneira, de seguir moito máis libremente os impulsos das miñas ansias de coñecemento. Debo dicir, non obstante, que eu atribúo o meu éxito en boa medida ao feito de que, aínda que posuía algún entendemento xeométrico e coñecía tamén a Física, tiven a boa fortuna de ser lanzado á Medicina, onde atopei na Fisioloxía un territorio virxe de gran fertilidade. Ademais, o meu coñecemento dos procesos vitais levoume a preguntas e puntos de vista que habitualmente son estraños aos matemáticos puros e aos físicos. Ata daquela só puidera comparar a miña habilidade matemática coa dos meus compañeiros de estudos e colegas médicos; o feito de que, en xeral, eu tivese un maior dominio ca eles neste aspecto quizais non sería dicir moito. Ademais, as Matemáticas foron consideradas sempre na escola como unha materia de importancia secundaria. 
O éxito chegoulle, efectivamente. En 1855 aceptou unha cátedra de Anatomía e Fisioloxía na Universidade de Bonn e en 1858 unha de Fisioloxía en Heidelberg. En 1871 recoñecíanse publicamente as contribucións que realizara no eido da Física cunha cátedra de Física na Universidade de Berlín. Finalmente, en 1888 foi nomeado presidente do Physikalisch-Technische Reichsanstal (Instituto Imperial de Física Técnica), acabado de crear, o primeiro laboratorio nacional da historia destinado a ocuparse de problemas relacionados coa investigación física que puidesen favorecer o desenvolvemento industrial.

O caso de Helmholtz e, en xeral, a relación entre Fisioloxía, Medicina, Química e Física durante o século XIX mostran que aínda que nos empeñemos en introducir divisións, existe unha unidade intrínseca na historia sen a que dificilmente poderemos comprender os seus aspectos máis interesantes. Así, o feito de que durante o século XIX se producise un avance espectacular nos saberes médicos é debido a que foi daquela cando as ciencias físico-químicas puxeron ao seu dispor os instrumentos imprescindibles ou, mellor, foron creando simultaneamente, cando menos nalgunhas ocasións.

\section{LOUIS PASTEUR, EXEMPLO DE CIENTÍFICO INTERDISCIPLINAR}

Louis Pasteur (1822-1895) é un dos grandes nomes da Historia, non xa da ciencia unicamente, mesmo da humanidade, pero eu vou utilizalo aquí como un exemplo de enfoques interdisciplinares.

Natural de Dole, no denominado Franco Condado, e fillo dun curtidor, tras estudar no Collège Royal de Besançon, onde obtivo o título de bacharelato en Letras (1840) e en Ciencias (1842), Pasteur foi admitido (1843) na sección científica da École Normale Supérieure e completou os seus estudos en 1845. Dous anos máis tarde logrou o grao de doutor pola Universidade de París cunha tese dividida en dúas partes, unha de Química e outra de Física; a primeira titulada Recherches sur la capacité de saturation de l'acide arsénieux. Étude des arsénites de potasse, de soude et d'ammoniaque (Investigacións sobre a capacidade de saturación do ácido de arsénico. Estudo dos arseniuros de potasio, a soda e o amoníaco) e a segunda, 1. Étude des phénomènes relatifs à la polarisation rotatoire des liquides. 2. Application de la polarisation rotatoire des liquides à la solution de diverses questions de Chimie 


\section{(1. Estudo de fenómenos relativos á polarización rotatoria dos líquidos. 2. Aplicación} da polarización rotatoria á solución de diversas cuestións de Quimica). Lonxe de ser un traballo correcto pero máis ou menos intranscendente, os contidos da súa tese, sobre todo os da segunda parte, pertencentes ao campo da Cristalografía e a Simetría Molecular, resultaron tan importantes que deron orixe a unha nova rama da ciencia: a Estereoquímica, que estuda as formas tridimensionais alternativas das moléculas. Con anterioridade á tese de Pasteur, era coñecida a existencia de dúas formas de ácido tartárico, unha que facía xirar o plano da luz polarizada cara á dereita, e outra que non o facía xirar en absoluto. Pasteur foi quen de illar un ácido tartárico, descoñecido daquela, que facía xirar a luz polarizada cara á esquerda e non cara á dereita, e de demostrar que o ácido tartárico que non facía xirar o plano de polarización da luz estaba composto de dous cristais diferentes, un o que producía xiros cara á dereita, e outro cara á esquerda; ao coexistir cristais que xiraban en sentidos opostos, o resultado era que se neutralizaban entre eles.

Comezou así un período da súa vida (1847-1857) dominado por este tipo de investigacións, no que se foi establecendo profesionalmente. En setembro de 1848 foi designado profesor de Física no Liceo de Dijon, pero permaneceu pouco tempo alí, xa que en decembro do mesmo ano foi nomeado profesor suplente de Química da Facultade de Ciencias da Universidade de Estrasburgo, na que ascendeu a catedrático titular en 1852. En 1854 marchou á Universidade de Lille, a cidade de maior actividade industrial do norte de Francia, como decano e profesor de Química da nova Facultade de Ciencias. En 1856, a Royal Society de Londres outorgoulle a prestixiosa medalla Rumford polos seus estudos de Cristalografía, un recoñecemento que seguramente lle serviu de axuda para acceder, o ano seguinte, a París, como administrador e director da rama de Ciencias da súa antiga alma mater, a École Normale Supérieure.

Coa instalación na capital, o centro neurálxico da vida francesa -incluída a científica-, os intereses profesionais de Pasteur pasaron ao dominio da Fermentación e Xeración Espontánea, ao que estivo dedicado plenamente ata 1865. Despois virían outras etapas da súa vida científica, centradas en investigacións sobre as enfermidades do verme de seda (1865-1870), estudos sobre a cervexa (1871-1876) e doenzas infecciosas (1876-1895).

Non é o noso obxectivo sequera bosquexar as motivacións e resultados do conxunto da obra de Pasteur, pero de entrada hai dous feitos salientables: por 
un lado, que foi un químico e físico que se ocupou de problemas médicos, e, por outro lado, que non eludiu as investigacións aplicadas. En realidade, ambos os aspectos da súa carreira están intimamente relacionados, nunha mestura case indisoluble na que se atopa unha parte importante da explicación dos seus éxitos. Por unha banda, estaban os seus coñecementos químicos e físicos, pola outra, non era alleo ao mundo que o rodeaba, ao mundo, por exemplo, da industria da seda ou da cervexa, o agrícola ou o das enfermidades. Estas dúas circunstancias levárono, nunha secuencia que ás veces un está tentado en considerar inevitable, dun tema de investigación a outro.

Así, os seus estudos sobre Disimetría molecular fixeron que se ocupase do alcohol amílico, activo tamén opticamente. Agora ben, resulta que o alcohol amílico desempeña un papel importante na fermentación láctica. Abríase desta maneira a porta ás investigacións de Pasteur sobre a fermentación, un feito que el mesmo recoñeceu e explicou na sección inicial do seu primeiro artigo neste campo, Memoria sobre a fermentación chamada láctica (1857), que habitualmente se considera que marca o inicio da Bacterioloxía como ciencia: «Penso que é o meu deber indicar con algunhas palabras como me vin conducido a ocuparme en investigacións sobre as fermentacións. Xa que aplicara ata o presente todos os meus esforzos en tratar de descubrir os vínculos que existen entre as propiedades químicas, ópticas e cristalográficas de certos corpos co obxectivo de aclarar a súa constitución molecular, talvez poida asombrar que aborde un tema de Química Fisiolóxica, moi afastado en aparencia dos meus primeiros traballos. Porén, están relacionados de forma moi directa».

Nas súas investigacións sobre a fermentación, Pasteur demostrou que esta era o resultado da acción de organismos vivos microscópicos; que non se producía cando se excluían ou aniquilaban -someténdoos, por exemplo, á acción da calor, a forma máis primitiva dun proceso que, tras ser perfeccionado, recibiu na súa honra o nome de pasteurización. Pasteur introducírase, quixese ou non, ao chegar a tales conclusións, nunha cuestión tan básica como de longa historia: a de saber se era posible a xeración espontánea, é dicir, se os seres vivos poden xurdir de substancias inanimadas. Durante as súas investigacións sobre a fermentación Pasteur deu por concluída de maneira definitiva esta cuestión. O lugar en que con máis rotundidade e claridade expresou os seus puntos de vista foi nun artigo publicado en 1862 titulado Memoria sobre os corpusculos organizados que exis- 
ten na atmosfera. Exame da doutrina das xeracións espontáneas. En primeiro lugar, demostrou que hai microorganismos que viven no aire que nos rodea e que poden contaminar mesmo o cultivo máis estéril. En segundo lugar, mostrou que cando un caldo de cultivo estéril era introducido nun recipiente selado no que non podía penetrar o aire, non xurdía alí microorganismo ningún. «Non, non hai circunstancia ningunha hoxe coñecida -manifestaba orgullosamente nunha conferencia que pronunciou na Sorbona en 1864, A xeración espontánea- na que se poida afirmar que seres microscópicos viñeran ao mundo sen xermes, sen pais semellantes a eles. Os que o pretenden foron xoguetes de ilusións, de experiencias mal feitas, cheas de erros que non souberon percibir ou evitar».

Establecido este punto, era razoable pensar en aplicar a nova teoría á orixe das doenzas. Tal convicción foi a que levou finalmente a Pasteur á investigación médica, que iniciou co estudo do ántrax ou carbuncho en 1877, cuxa causa asociou tamén cun microorganismo, a bacteridia. Nunha conferencia que leu ante a Academia de Medicina de París en 1978 -e en cuxa preparación foi axudado por dous dos seus colaboradores, Jules-François Joubert e Charles Chamberland-, titulada $A$ teoría dos xermes e as súas aplicacións á Medicina e á Cirurxía, Pasteur explicou con claridade a orixe e natureza dos seus intereses médicos e algúns dos problemas cos que se atopaba:

Todas as ciencias gañan cando se prestan un apoio mutuo. Cando despois das miñas primeiras comunicacións sobre as fermentacións en 1857-1858 se pode admitir que os fermentos son seres vivos, que na superficie de todos os obxectos, na atmosfera e nas augas hai moitos xermes de organismos microscópicos, que a hipótese dunha xeración espontánea é unha quimera, que o viño, a cervexa, o vinagre, o sangue, os ouriños e todos os líquidos do organismo non sofren ningunha das súas alteracións comúns en contacto co aire puro, a Medicina e a Cirurxía dirixiron os seus ollos a estas novidades tan evidentes. Un médico francés, o doutor [Casimir Joseph] Davaine, fixo a primeira aplicación con éxito destes principios á Medicina en 1863.

As nosas investigacións durante o último ano avanzaron moito menos na Etioloxía da enfermidade pútrida ou septicemia que na do carbuncho. Criamos que a septicemia dependía da presenza e multiplicación dun organismo microscópico, pero non se puido demostrar con certeza esta importante conclusión. Para afirmar de modo experimental que un organismo microscópico é, en realidade, o axente da enfermidade e o contaxio, 
non vexo outro medio, no estado actual da ciencia, que o de someter o microbio - nova e feliz expresión proposta por Sédillot [1878]- ao método dos cultivos fóra do organismo.

\section{FÍSICA E MATEMÁTICAS: NEWTON E EINSTEIN}

A relación entre Matemáticas e Física é doutro tipo ao que tratei nos exemplos precedentes. É antiga e está ben establecida, polo que ben podería prescindir de aclarala aquí. Non obstante, a súa importancia merece que lle dedique algúns comentarios. Para comezar, temos o caso de Isaac Newton (1642-1727) a propósito da invención do cálculo diferencial.

Sería erróneo considerar que Newton chegou ao cálculo diferencial e integral unicamente porque desexaba un instrumento adecuado para construír unha teoría do movemento, unha dinámica. Por suposto que tal apartado se atopaba entre os seus obxectivos científicos, pero tamén o estaban problemas de Matemáticas como calcular a tanxente dunha curva en calquera dos seus puntos, algo que require da derivación, o mesmo ente matemático que describe a velocidade coa que se move un corpo. En todo caso -e este é o punto que me interesa resaltar agora-, do que non hai dúbida é de que o feito de que en Newton se reunisen as habilidades matemáticas e físicas foi esencial para que puidese producir esa xoia inmortal do pensamento científico que é Principios matemáticos da Filosofía Natural (1687), os Principia.

Un caso diferente, pero tamén ilustrativo, é o de Albert Einstein (1879-1955) e o papel que a Matemática desempeñou na construción da súa teoría da relatividade xeral.

Contra 1912, Einstein chegou á conclusión de que a teoría relativista da gravitación que buscaba debía basearse nun espazo-tempo cuxa xeometría dependese do seu contido enerxético-material, ou, noutras palabras, que a gravitación curva o espazo-tempo. Sería este, en consecuencia, non só unha variedade métrica senón tamén de Xeometría Variable, non prefixada e inmutable que acontecía con todas as teorías físicas coñecidas ata daquela. Máis aínda, o obxecto matemático que describía esa Xeometría debía ser igual que o que describise a forza gravitacional. Neste sentido, a gravitación xeometrizábase, é dicir, incluía, subsumía a gravitación na Xeometría. Einstein necesitaba, xa que logo, unha 
Xeometría máis complexa e xeral que a clásica establecida nos Elementos de Euclides, a Xeometría dos espazos bi ou tridimensionais planos, a que contén un postulado -o quinto- que afirma que por un punto exterior a unha recta só pode pasar unha paralela a esta; a Xeometría en que se cumpren propiedades tan familiares como a de que os ángulos interiores dun triángulo suman 180 graos. Afortunadamente, a base desa Xeometría $n$-dimensional curva establecérase durante o século XIX. En efecto, os repetidos esforzos encamiñados para demostrar que o quinto postulado dos Elementos de Euclides era unha peza superflua na estrutura da obra, que se podía deducir doutros axiomas, levaron, durante o primeiro terzo do século XIX, á sorprendente conclusión de que non só era realmente independente, senón que da súa negación non se deducían contradicións, é dicir, que se pode substituír por outros postulados alternativos que conducen a Xeometrías diferentes da euclídea, pero loxicamente correctas. Estoume a referir ás Xeometrías asociadas primordialmente aos nomes de Carl Friedrich Gauss (1777-1855), Nicolai Ivanovich Lobachevskii (1792-1856) e Janos Bolyai (1802-1860). Inicialmente, o descubrimento das Xeometrías non euclídeas non produciu un excesivo interese, pero unha combinación de sucesos relanzou o seu estudo. En primeiro lugar, está a publicación, entre 1860 e 1865, da correspondencia de Gauss co seu amigo, o astrónomo Heinrich C. Schumacher (1780-1850), coa súa referencia favorable ao traballo de Lobachevskii. En segundo lugar, a demostración de Eugenio Beltrami (1835-1899), en 1868, de que a Xeometría de Lobachevskii se podía interpretar como a Xeometría dunha superficie de curvatura constante e negativa. Finalmente, está a lección de habilitación que Bernhard Riemann (1826-1866) pronunciou en 1854: Sobre as hipóteses que lle serven de fundamento á Xeometría; de aí que sexa común falar de «espazos riemannianos».

O problema para Einstein é que recoñecía a necesidade de acudir a unha Xeometría curva non estática, pero non dispoñía dos coñecementos precisos. A axuda chegoulle dun amigo e compañeiro de estudos no Politécnico de Zúric, Marcel Grossmann (1878-1936), que xa interviñera decisivamente na súa vida anos antes, en 1902, cando o pai de Grossmann logrou que a Oficina de Patentes de Berna lle dese un emprego ao daquela desvalido Albert. Cando en febreiro de 1912 Einstein foi nomeado catedrático na súa antiga alma mater, o Instituto Politécnico de Zúric, atopou alí a Grossmann, que ocupaba unha cátedra 
de Matemáticas. Foi unha coincidencia afortunada, xa que Grossmann se especializara precisamente en Xeometría Diferencial. Xuntos escribiron un artigo que representa un momento decisivo na carreira de Einstein, así como na historia da Física. Na carreira de Einstein porque o estilo einsteniano cambiaría dunha maneira radical desde aquela. $\mathrm{Na}$ historia da Física porque ata ese momento non fixera ninguén o que os seus autores levaron a cabo naquel traballo: reducir, xeometrizar, a gravitación; utilizar un marco xeométrico curvo que dependía do seu contido enerxético-material.

$\mathrm{O}$ artigo en cuestión, que a editorial Teubner decidiu publicar a fins de 1913 como un folleto de vinte e oito páxinas, titulábase Bosquexo dunha teoría xeral da relatividade e dunha teoría da gravitación. A súa estrutura non deixaba dúbidas no tocante ás diferentes responsabilidades dos seus autores: comezaba cunha «Parte física», asinada por Einstein, e continuaba cunha "Parte matemática», debida a Grossmann.

As ecuacións do campo gravitacional que se propoñían neste Bosquexo non eran correctas e Einstein acabaría abandonándoas. Comezou daquela un longo, complexo e acotío escuro, conceptualmente, período -que só finalizaría en novembro de 1915- durante o que Einstein teimou por determinar os principios básicos da teoría relativista da gravitación que buscaba, incluíndo, claro, as ecuacións do campo gravitacional. Pero, para os meus propósitos aquí, o realmente importante é sinalar que, aínda que os argumentos físicos non desapareceron dos razoamentos de Einstein, cada vez ían cobrando máis forza os puramente matemáticos, co cálculo tensorial ocupando unha posición central. A fascinación que Einstein ía sentindo polo poder das Matemáticas queda demostrada na pasaxe inicial do artigo que leu na sesión plenaria da Academia Prusiana de Ciencias, o catro de novembro de 1915, na que quedou a un paso de formular a versión final da teoría da relatividade xeral: "Ninguén que a entendera realmente [a teoría métrica que presentaba alí] pode escapar da súa fermosura, porque significa o verdadeiro triunfo do cálculo diferencial absoluto tal e como fora fundado por Gauss, Riemann, Christoffel, Ricci e Levi-Civita».

Vinte e un días despois, o vinte e cinco de novembro de 1915, Einstein presentaba na Academia Prusiana a formulación definitiva da teoría xeral da relatividade, é dicir, a formulación que incluía as ecuacións correctas do campo gravitacional, expresadas, por suposto, en forma tensorial. 
A partir dese momento, Einstein, o vello seguidor da Filosofía de Ernst Mach (1838-1916), sucumbiu ao poder da Matemática como guía heurística para a Física Teórica, aínda que, é verdade, non esqueceu nunca que o xuíz definitivo dunha teoría física é sempre a experiencia. De feito, podemos dicir que no tocante á súa relación de madurez coas Matemáticas, Einstein recuperou sensacións que xa experimentara cando tiña doce anos, cando, como lembrou nas súas Notas autobiográficas, lle caeu nas súas mans un libriño sobre Xeometría euclídea. "Había alí asertos - recordaba daquela- como a intersección das tres alturas dun triángulo nun punto, por exemplo, que -aínda que en modo ningún evidentes- se podían probar con tanta seguridade que semellaban estar a salvo de toda dúbida. Esta claridade, esta certeza, exerceu sobre min unha impresión indescritible [...]. Aínda que parecía que a través do pensamento puro era posible lograr un coñecemento seguro sobre os obxectos da experiencia, o "milagro" descansaba nun erro. Mais, para quen o vive por primeira vez, non deixa de ser bastante marabilloso que o home sexa quen de lograr, sequera no pensamento puro, un grao de certeza e pureza como o que os gregos mostraron por primeira vez na Xeometría».

Da man da teoría da relatividade xeral, redescubriu, poderíamos dicir, o poder da Matemática; así, a partir dun determinado momento, contra 1920, non atopou máis guía heurística para proseguir a súa procura dunha teoría do campo unificado - unha teoría que reunise as forzas electromagnética e gravitacional-, que a Matemática. Moi ilustrativo é o que dixo na conferencia Herbert Spencer que pronunciou en Oxford o dez de xuño de 1933:

Se é verdade [...] que a base axiomática da Física Teórica non pode ser extraída da experiencia e debe ser inventada con liberdade, podemos agardar que algunha vez atopemos o camiño correcto? [...]. Sen vacilación ningunha responderei que, ao meu ver, existe un camiño correcto e que nós somos quen de o atopar.

Ata o momento presente, a nosa experiencia autorízanos a crer que a natureza é a realización das ideas matemáticas máis simples que se poida concibir. Estou convencido de que, por medio de construcións matemáticas, podemos descubrir os conceptos e as leis que os conectan entre eles, que son os elementos que proporcionan a clave para a comprensión dos fenómenos naturais. A experiencia pode suxerir os conceptos matemáticos apropiados, pero estes, sen dúbida ningunha, non poden ser deducidos dela. 
Por suposto que a experiencia retén a súa calidade de criterio último da utilidade física dunha construción matemática. Pero o principio creativo reside na Matemática. Xa que logo, en certo sentido, considero que o pensamento puro pode captar a realidade, como os antigos soñaran.

\section{MATEMÁTICAS E ECONOMÍA: THE THEORY OF GAMES AND ECONOMIC BEHAVIOR, DE JOHN VON NEUMANN E OSKAR MORGENSTERN}

A relación entre Física e Matemáticas constitúe un bo exemplo do papel beneficioso que para ambas as dúas disciplinas significa a súa relación, pero resulta moi coñecido e oculta o papel que a Matemática desempeña noutras materias, como a Economía. Para comentar esta relación, vou utilizar algunhas pasaxes do capítulo I dun libro clásico na Economía Matemática: Theory of Games and Economic Behavior, do matemático John von Neumann e o economista Oskar Morgenstern, publicado en 1944 por Princeton University Press.

No apartado 1.2, titulado «Dificultades na aplicación do método matemático», e tras sinalar algunhas das características da Economía que dificultaban a posibilidade de que xa se dispuxese dunha teoría económica satisfactoria, Von Neumann e Morgenstern escribían: «A Matemática utilizouse na teoría económica, talvez mesmo de forma esaxerada. Pero este uso non obtivo demasiado éxito. Isto é contrario ao que vemos noutras ciencias: nelas, a Matemática foi aplicada con grande éxito, e a maioría das ciencias dificilmente poden sobrevivir sen ela». O motivo que xustifica este feito residía, ao seu ver, en que «os problemas matemáticos non se formularon con claridade e decote son presentados en termos tan vagos que fan que un tratamento matemático pareza a priori imposible». Ademais, "o substrato empírico da ciencia económica é definitivamente inadecuado». Malia todo isto, eles pensaban na «posibilidade dun tratamento matemático destes fenómenos». Agora ben, e isto é o que me importa destacar, crían que seguramente sería preciso desenvolver novas ideas e técnicas matemáticas:

A importancia dos fenómenos sociais, a riqueza e multiplicidade das súas manifestacións e a complexidade das súas estruturas son, como mínimo, iguais que as da Física. Xa que 
logo, cómpre agardar -ou temer- que se precisarán descubrimentos matemáticos dunha estatura comparable á do cálculo para producir avances decisivos neste eido [...]. A fortiori é improbable que unha mera repetición dos trucos que serviron tan ben na Física sexan tamén válidos para os fenómenos sociais.

Noutras palabras, Von Neumann e Morgenstern estaban a reclamar un tipo de esforzo interdisciplinar; que se intentase ir alén do método científico tradicional no que o uso da Matemática estaba determinado segundo o modelo e o exemplo da Física, e en particular da Física newtoniana. Isto requiriría de novas ideas matemáticas, algo que sería beneficioso para a teoría económica, si, pero tamén para a propia Matemática. De feito, Theory of Games and Economic Behavior avanzaba en tal dirección, ao utilizar profusamente a teoría de xogos, da que o propio Von Neumann é considerado o pai (Von Neumann, 1928, p. 295-300).

Agora ben, a teoría de xogos que se utilizaba en Theory of Games and Economic Behavior era a de xogos cooperativos, e, na realidade, tanto social como económica, non sempre se coopera. Un avance notable na dirección de aproximarse á realidade económica viría -igual que aconteceu no caso do artigo de Von Neumann de 1928- da man do matemático John Nash; máis concretamente, da tese de doutoramento que este completou en Princeton en 1950: Non-Cooperative Games. Podemos considerar unha homenaxe á interdisciplinariedade o feito de que en 1994 Nash recibise, xunto con John Harsanyi e Reinhard Selten, o Premio Nobel de Economía.

\section{INTERDISCIPLINARIEDADE NAS CIENCIAS DA TERRA}

As Ciencias da Terra ofrecen outro bo exemplo do frutífera que é a interdisciplinariedade, a reunión de diferentes ciencias na procura dun obxectivo común, o de comprender mellor a natureza.

Quero referirme, en particular, aos problemas que atopou a teoría da evolución das especies de Darwin, que necesitaba un pasado moi dilatado, na Física do dezanove. É ben coñecida, en concreto, a oposición que Kelvin presentou ao argumentar que, segundo a Física coñecida daquela -que se consideraba moi 
próxima á definitiva-, a Terra tiña un pasado que non bastaba para admitir as lentas evolucións que Darwin supoñía que nela aconteceran.

O problema residía non só en que a Física clásica distaba de ser correcta -e pronto se vería que así o era co descubrimento dos raios $\mathrm{X}$ e da radioactividade-, senón tamén no moito que se descoñecía da estrutura da Terra. De feito, e malia o descubrimento, en 1896, da radioactividade, ata mediados da década de 1920 moitos - a maioría, probablemente- sismólogos aceptaban a teoría de Kelvin de que o interior da Terra era sólido. As diferenzas nas velocidades das ondas podían ser debidas non a cambios no estado físico -sólido ou líquido-, senón na densidade dos materiais, e producidas por modificacións na composición química. Ademais, o feito de que a temperatura do interior da Terra fose aumentando coa profundidade non implicaba necesariamente que o interior se fundise, converténdose en líquido; era sabido que o punto de fusión dunha substancia aumenta coa presión e esta, obviamente, crece coa profundidade.

Agora ben, despois de que Henri Becquerel descubrise en 1896 a radioactividade e de que dous anos despois Marie e Pierre Curie ampliasen a lista de elementos radioactivos -inicialmente formada só polo uranio- co polonio e o radio, resultou que non era necesario que a temperatura do interior da Terra aumentase para explicar a xeración de calor, que tanto preocupara a Kelvin: os elementos radioactivos producíronse de forma natural durante períodos de tempo extremadamente longos.

A introdución da radioactividade nas Ciencias da Terra constituíu un feito decisivo. Vexamos como exemplo os traballos do xeofísico irlandés John Joly (1857-1933). Educado como físico, Joly demostrou que os aneis escuros que se observan na mica se debían á radiación producida por pequenas inclusións de materiais, como a apatita, que conteñen uranio e torio. A conclusión inevitable era que estes elementos radioactivos abundan nas rochas e, xa que logo, na natureza, constituíndo así unha fonte ubicua de calor. E se acontecía isto, había unha forza de transformacións xeolóxicas. Joly propuxo -por exemplo, nun libro publicado en 1925, The Surface-History of the Earth- que cando se ía acumulando esta calor radioactiva, o substrato terrestre comezaba a fundirse. Produciríanse episodios de fundición, durante os que os continentes se moverían baixo a influencia de forzas pequenas, tales como pequenos efectos gravitacionais que noutras condicións non producirían efecto ningún. Para Joly, estas funcións 
periódicas poderían asociarse a ciclos magmáticos durante os cales se formarían montañas.

Un ano antes da publicación do devandito libro de Joly aparecera outro que resultou moi influente, The Earth; definiu, de feito, durante anos o campo da Física do interior da Terra. O seu autor, o matemático, astrónomo e xeofísico británico Harold Jeffreys (1891-1989), argumentaba nel que cando menos unha boa parte do núcleo da Terra debe ser fluído. Entre as técnicas que utilizaba destacaban as análises físico-matemáticas de propagación de ondas. Tales técnicas, desenvolvidas basicamente durante o século XIX, permiten distinguir entre ondas lonxitudinais, producidas por un medio que se comprime e expande sucesivamente, e transversais, debidas a un medio que se curva, que en Sismoloxía se denominan, respectivamente, ondas $\mathrm{P}$ e $\mathrm{S}$. As ondas lonxitudinais $(\mathrm{P})$ poden propagarse en calquera substancia que resista á compresión e tenda a recuperar o seu volume inicial cando se elimina a presión, algo que acontece tanto en sólidos como en líquidos ou gases. Pola contra, as ondas $S$ unicamente se poden producir en sólidos.

Como vemos, as técnicas e teorías físicas foron imprescindibles para avanzar no coñecemento da Terra; de aí o nome de Xeofísica.

\section{FÍSICA E XEOFÍSICA}

Neste punto, non obstante, teño que facer un alto e unha precisión: a de que a alianza, a colaboración entre Física e Xeoloxía non foi fácil, institucionalmente, no comezo.

Vexamos, neste sentido, o que, lembrando os seus estudos na Universidade de Toronto, manifestou Lawrence Morley, quen realizou importantes contribucións ao Paleomagnetismo.

Morley comezou a estudar Matemáticas e Física en 1938, pero axiña -no seu segundo ano- pasou a cursar Física e Xeoloxía. "Decateime pronto de que este curso pretendía ser un experimento interdisciplinar e de que só estabamos matriculados dous estudantes, e ademais unicamente existía un estudante graduado nos últimos seis anos, J. Tuzo Wilson, que despois foi o meu supervisor de tese e un dos membros do grupo que produciu a teoría e o nome de tectónica de placas». 
Morley tamén se decatou enseguida do "gran golfo que existía daquela entre a mente dun xeólogo e a dos físicos. Estes consideraban inferior a Xeoloxía e víana como un campo descritivo e cualitativo que non era realmente unha ciencia; e os xeólogos pensaban que os físicos eran "cabezas de ovo" que non vivían no mundo real. Non é preciso dicir que os dous grupos tiñan dificultades para comunicarse profesionalmente entre eles. O curso de Física e Xeoloxía foi establecido de maneira que a metade das miñas clases eran impartidas no Departamento de Xeoloxía e a outra metade no de Física. Pasarían algúns anos ata descubrir a forma de unir ambos os campos».

\section{A DERIVA DOS CONTINENTES}

Cando se fala das Ciencias da Terra e do século XX, resulta inevitable mencionar o meteorólogo e xeofísico alemán Alfred Wegener (1880-1930). Aínda que outros antes que el mencionaron a idea pola que é lembrado, foi Wegener o que con máis argumentos e insistencia propuxo, primeiro en 1912 e despois nun libro que publicou en 1915, Die Entstehung der Kontinente und Ozeane (A orixe dos continentes e océanos), a idea de que os continentes se atopan en movemento; que no Pérmico, é dicir, hai máis de douscentos cincuenta millóns de anos, e durante o Triásico, hai entre douscentos corenta e cinco e douscentos oito millóns de anos, os bloques continentais que coñecemos estaban agrupados nun gran supercontinente, Panxea. Máis tarde, no Xurásico, hai entre douscentos oito e cento corenta e catro millóns de anos, apareceu a primeira fisura entre Europa e África e iniciouse un proceso que conduciu á Xeografía Continental actual.

Afortunadamente, a ciencia non progresa sempre sen incoherencias, e é que a idea de Wegener non casaba particularmente ben coa teoría de Kelvin de que o interior da Terra era sólido. Todo o contrario, dificultábaa enormemente. Como se ían producir estes movementos nun substrato sólido?

Wegener, un personaxe extraordinariamente interesante -combinou os seus intereses académicos coa exploración polar, que aplicaba a investigacións meteorolóxicas e xeolóxicas; morreu cando cruzaba o casquete ártico de Groenlandia, durante a súa cuarta expedición polar-, referiuse no seu libro á orixe das súas ideas nos seguintes termos: 
Tiven a primeira intuición da mobilidade continental xa en 1910, cando, ao contemplar un mapamundi, me impresionou a coincidencia das costas de ambos os lados do Atlántico; pero naquel momento non fixen caso desta idea, que me pareceu inverosímil. No outono de 1911 souben, a través dun traballo de síntese que caeu nas miñas mans por casualidade, dos resultados paleontolóxicos, para min descoñecidos ata daquela, referentes ás primitivas conexións continentais entre Brasil e África. Isto levoume a un exame atento, aínda que polo momento fugaz, dos resultados das investigacións xeolóxicas e paleontolóxicas referidas a esta cuestión, investigacións que produciron enseguida confirmacións tan importantes que fixeron arraigar en min o convencemento de que eran basicamente correctas.

Agora ben, a simple observación da similitude entre os perfiles orientais e occidentais de, respectivamente, Suramérica e África non era suficiente para concluír que no pasado formaran parte dun mesmo continente -en 1620, Francis Bacon, por exemplo, xa se decatara de tal coincidencia, pero non pasou de aí. Tampouco era nova a observación do parentesco animal e vexetal entre ambos os lugares, deducido dalgúns restos fósiles atopados a ambos os dous lados do Atlántico.

Wegener descubriu que a distribución xeográfica das miñocas da terra proporcionaba bos argumentos en favor da teoría da deriva dos continentes. Tamén se preguntou por que se produciran glaciacións en certas épocas pasadas en continentes que agora son tropicais. Foi, en suma, un extenso conxunto de observacións e argumentacións paleontolóxicas e biolóxicas, paleoclimáticas, xeolóxicas e xeodésicas, entrelazadas todas polo fío común da súa interpretación, o que dotou de forza a súa idea. Porén, durante case medio século non foron demasiados os que aceptaron estes puntos de vista. Existía un problema fundamental: mediante que mecanismo se desprazan os continentes? Unha situación que fai lembrar a Galileo, que carecía dunha mecánica que puidese soster a observación de que non sentimos que a Terra se mova, ou a Charles Darwin, que non dispoñía dunha teoría da herdanza que puidese sustentar a súa teoría da evolución e selección natural.

A determinación e a comprobación das translacións continentais relativas realizouse -escribía Wegener no antepenúltimo capítulo do seu libro- dunha forma puramente 
empírica, a partir da totalidade dos datos xeodésicos, xeofísicos, biolóxicos e paleoclimáticos, pero sen facer consideración ningunha sobre a orixe destes procesos. Este é o método indutivo, método que as Ciencias Naturais se ven forzadas a empregar na meirande parte dos casos. As fórmulas das leis da gravidade e das órbitas planetarias determináronse nun principio dunha forma puramente indutiva, por observación; só despois apareceu Newton e mostrou como derivar estas leis dedutivamente a partir da fórmula única da gravitación universal [...]. Aínda non apareceu o Newton da teoría dos desprazamentos.

O feito de que Wegener se decatase de que aínda non aparecera o «Newton da teoría dos desprazamentos» non quere dicir, porén, que se abstivese de propoñer algún mecanismo que explicase, cando menos grosso modo, o movemento continental. Utilizando diversos datos e teorías xeofísicas, argumentaba que os continentes, que consideraba formados por sial -silicio e aluminio, que corresponden a rochas de granito- flotaban, como icebergs, sobre os máis densos fondos mariños e continentais, formados por sima -silicio e magnesio- ou rochas de basalto, e que o seu movemento se debía a forzas de marea producidas pola Lúa, xunto a unha forza centrífuga debida á rotación da Terra.

Pero este mecanismo non convenceu aos xeólogos contemporáneos de Wegener, nin tampouco aos das décadas seguintes: habería que esperar a despois da Segunda Guerra Mundial e ao avance experimentado pola investigación oceanográfica, impulsada polo desexo das grandes potencias de coñecer a Xeografía e a Xeoloxía dos fondos mariños. Non hai que esquecer a importancia política e militar que posuían os submarinos nucleares ou convencionais, que fixeron dos océanos unha potencial fronte bélica durante a Guerra Fría.

En particular, os estudos realizados sobre fondos mariños durante o Ano Xeofísico Internacional de 1957 marcaron o punto de partida efectivo dunha serie de resultados importantes, entre os que cómpre mencionar: os estudos de Paleomagnetismo -o magnetismo que queda nas rochas cando se forman por solidificación a partir do magma- levados a cabo polos físicos británicos Patrick Blackett (1897-1974) e Keit Runcorn; a análise dos fluxos caloríficos nas fallas e dorsais oceánicas a cargo do xeofísico británico Edward Bullard (1907-1980); os traballos relativos á actividade sismolóxica de fondos mariños realizados polos norteamericanos Maurice Ewing e Bruce Essen; anomalías gravitacionais 
detectadas polo xeofísico holandés Felix Andries e o norteamericano Harry Hess (1906-1969). Foi este último, Hess, o que reuniu estes resultados e propuxo en 1960 a hipótese coñecida despois como «expansión dos fondos mariños», que foi confirmada a mediados daquela década polos xeofísicos británicos Frederich Vine (1939-1988) e Drummond Matthews (1931-1997), ao analizar os patróns que seguían as anomalías magnéticas a ambos os lados das dorsais oceánicas.

O estudo das anomalías magnéticas en certas liñas dos fondos oceánicos foi particularmente importante e paga a pena que me deteña nel, entre outras razóns porque é un dos lugares en que a Física se mostrou máis relevante para as Ciencias da Terra.

É ben sabido que a Terra posúe un campo magnético similar ao que ten un imán en forma de barra, cos polos magnéticos sur e norte coincidindo aproximadamente cos dous extremos do eixe arredor do que xira a Terra. Se supoñemos que non se produciron nunca variacións no campo magnético terrestre, daquela, medindo a inclinación do campo magnético obtemos a latitude xeográfica na que se formou unha rocha.

A magnetización remanente das rochas sedimentarias e ígneas prodúcese das seguintes maneiras:

Nas de orixe sedimentaria, o mineral que lles dá a capacidade de reter o magnetismo terrestre é, sobre todo, a hematita $\left(\mathrm{Fe}_{2} \mathrm{O}_{3}\right)$. Segundo as partículas se van sedimentando en augas turbias, cada gran de hematita fai como a pequena agulla dun compás que se aliña na dirección do campo magnético terrestre. Cando se compacta con outros minerais non ferromagnéticos, toda a rocha toma a dirección do campo xeomagnético, retendo esta magnetización indefinidamente, agás no caso en que sexa magnetizada de novo, quentándoa a temperaturas elevadas e arrefriándoa ou someténdoa a un gran campo magnético.

As rochas ígneas reciben a súa magnetización do campo terrestre cando se arrefrían por debaixo do "punto de Curie», que na magnetita $\left(\mathrm{Fe}_{3} \mathrm{O}_{4}\right)$, o mineral máis común nas rochas ígneas, corresponde a $582^{\circ} \mathrm{C}$.

Foi, efectivamente, Pierre Curie o que descubriu que cando se quenta un material ferromagnético por riba de certa, e alta, temperatura -agora chamado o "punto de Curie»- perde por completo o seu magnetismo remanente. Reciprocamente, cando se arrefría partindo dunha temperatura superior á do "punto 
de Curie», logra un intenso e permanente magnetismo remanente na dirección do campo magnético terrestre.

Xa que logo, se ao longo da historia da Terra variou o seu campo magnético, tales variacións poderíanse detectar nas rochas, en particular nas volcánicas que comezaron a súa vida en magmas a temperaturas superiores ás do "punto de Curie». E a mediados de século existían indicacións a favor de que na Terra se produciran variacións xeomagnéticas seculares. Foi un físico, Walter Elsasser (1904-1991), o que primeiro propuxo, en 1939, que o magnetismo terrestre se debe a correntes termoeléctricas no núcleo líquido terrestre, que se producen debido á existencia de fontes radioactivas de calor. Tras deter as súas investigacións, por mor da guerra, en 1946, Elssaser volveu a este campo e desenvolveu os seus traballos anteriores. Descubriu, en particular, que podían existir campos toroidais no núcleo e que proporcionarían mecanismos de amplificación do campo. Ademais, decatouse de que a súa teoría predicía a aparición de cambios seculares no campo magnético terrestre.

Obviamente, este apoio teórico favoreceu os traballos de Vine e Matthews nos que analizaron os modelos que seguían as anomalías magnéticas a ambos os lados das dorsais oceánicas, imprescindibles para a nova teoría que xurdiu.

Con resultados como os anteriores, finalmente en 1965, Tuzo Wilson introduciu a idea de que a superficie terrestre está formada por varias capas ríxidas pero móbiles. Segundo esta nova síntese, denominada Tectónica de Placas, non son só os continentes os que se moven, senón tamén zonas máis extensas da codia terrestre - placas-, que inclúen partes dos océanos e masas continentais. As placas -seis grandes e varias máis pequenas- móvense sobre estratos máis profundos e a súa forza motriz son as correntes lentas de magma viscoso; o magma é o material fundido que existe no interior da Terra, do que se forman as rochas ígneas; a lava é magma que alcanzou a superficie e que se solidifica perdendo algúns dos seus compoñentes no camiño. 
A INTERDISCIPLINARIEDADE Á LUZ DA HISTORIA DA CIENCIA: ALGÚNS EXEMPLOS

\section{Bibliografía}

Von Neumann, J.: «Zur theorie der Gesellschafsspiele», en Mathematische Annalen 100, 1928, p. 295-300 . 